\title{
Neoseiulus californicus McGregor: A Predatory Mite Species for Controlling Twospotted Spider Mites in Strawberries 1
}

Silvia I. Rondon, James F. Price, Oscar E. Liburd, Roger Francis, Daniel J. Cantliffe ${ }^{2}$

Neoseiulus californicus McGregor (Acari:

Phytoseiidae) is an oblong, tiny, mobile, predatory

mite that feeds on a variety of prey (Fig. 1). It

belongs to the suborder Acariforme in the Acari

order. The division includes more than 30,000

described species included in the ancient group of

Arachnida (Krantz, 1978).

- Phylum: Arthropoda

- Class: Arachnida

- Order: Acari

- Family: Phytoseiidae

- Genus: Neoseiulus (Amblyseius)

- Species: californicus

Neoseiulus californicus occurs in warm humid areas of the U.S., South America, Europe, and

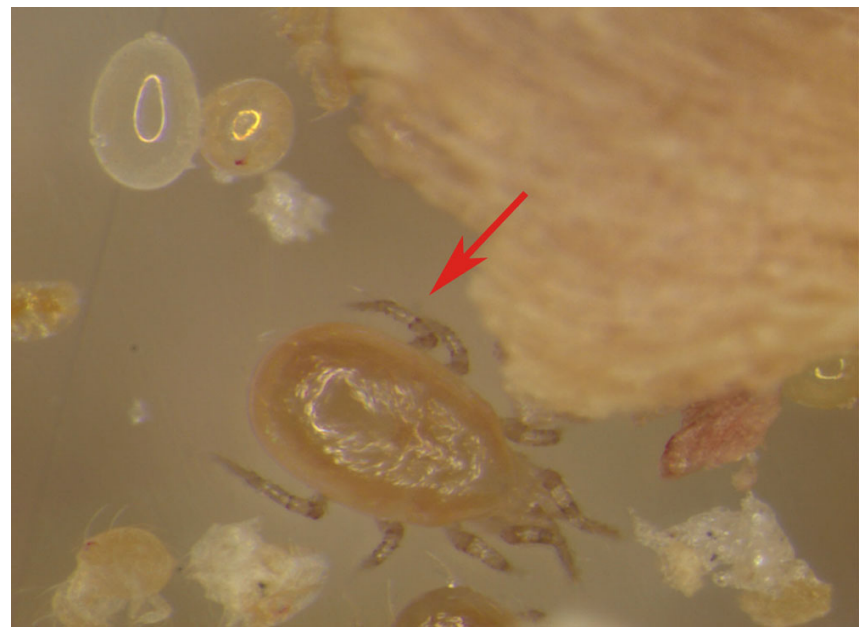

Figure 1. Adult of Neoseiulus californicus $(0.1 \mathrm{~mm}$ in length X $0.06 \mathrm{~mm}$ in width). Credits: E. Jovicich, UF/IFAS

systems including strawberries, raspberries, roses, grapes, citrus, ornamentals, and vegetables (Rondon et al. 2004; Liburd et al. 2003; Hoddle, 2000; Johnson and Lyon, 1991). elsewhere around the Mediterranean Sea (Malais and Ravensberg, 2003; McMurty, 1982). This predatory mite is associated with several agricultural cropping

1. This document is HS1001, one of a series of the Horticultural Sciences Department, Florida Cooperative Extension Service, Institute of Food and Agricultural Sciences, University of Florida. Publication date: November 2004. Please visit the EDIS Web site at http://edis.ifas.ufl.edu.

2. Silvia I. Rondon, adjunct research associate, Horticultural Sciences Department; James F. Price, associate professor, GCREC-Bradenton; Oscar E. Liburd, assistant professor, Entomology and Nematology Department; Roger Francis, Clemson Extension Service, St. Charleston, South Carolina; Daniel J. Cantliffe, professor and chair, Horticultural Sciences Department, Cooperative Extension Service, Institute of Food and Agricultural Sciences, University of Florida, Gainesville, 32611. 


\section{Host Range}

Neoseiulus californicus feeds on important fruits and ornamental pests such as the twospotted spider mite (Tetranychus urticae Koch) (Fig. 2), broad mite (Polyphagotarsonemus (Stenotarsonemus) latus Banks) (Fig. 3), cyclamen mite (Tarsonemus pallidus L.) (Fig. 4 and Fig. 5), and other mite species (Hoddle, 2000).

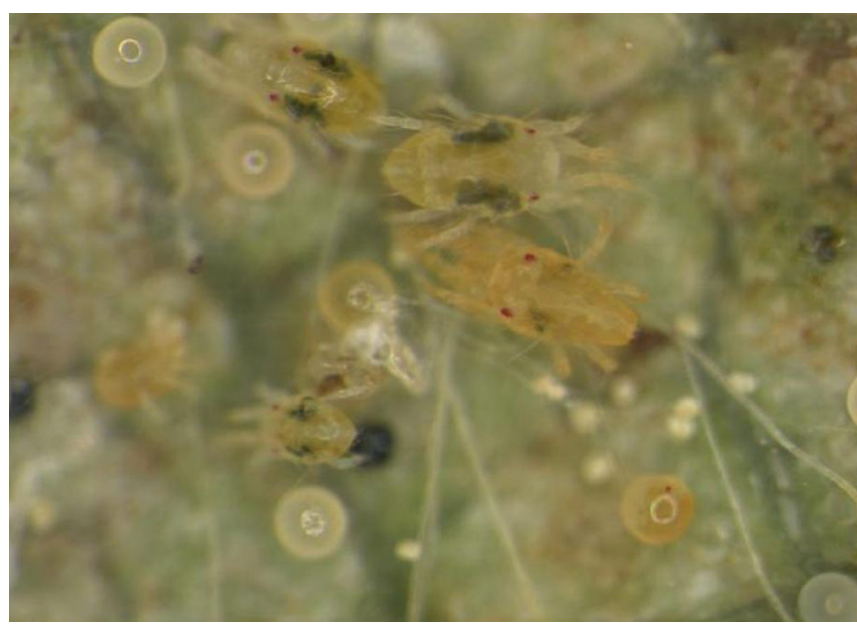

Figure 2. Group of twospotted spider mite adults and eggs, (0.15 mm in length $X 0.1 \mathrm{~mm}$ in width). Credits: J.F. Price and S.I. Rondon, UF/IFAS

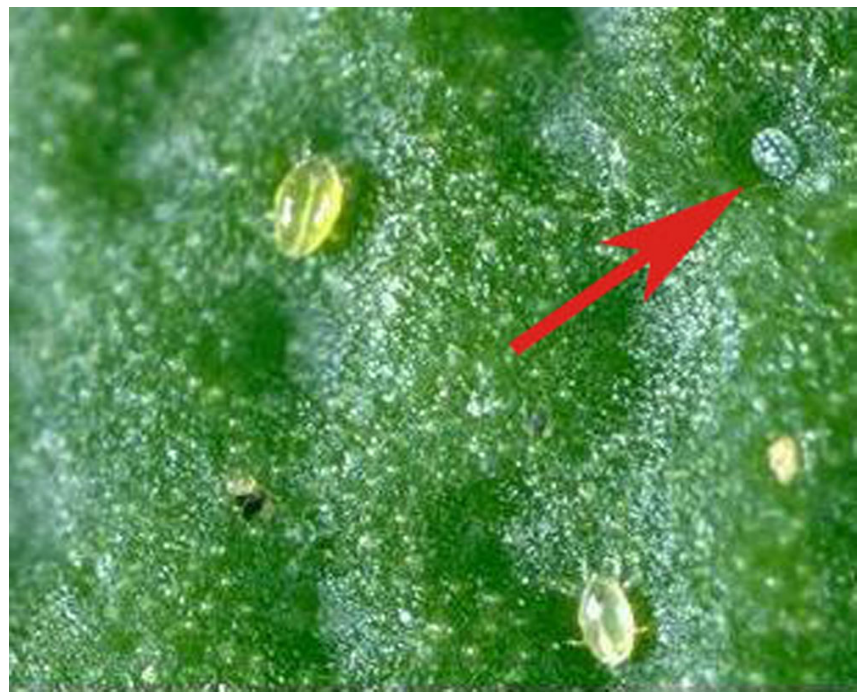

Figure 3. Broad mite $(0.02 \mathrm{~mm}$ in length $X 0.01 \mathrm{~mm}$ in width). Arrow shows the egg. Credits: J. Castellanos, UF/IFAS

\section{Life Cycle and Biology}

Neoseiulus californicus possesses three life stages: egg, nymph, and adult. Eggs are oblong (football shape), small, and pale. The two nymphal

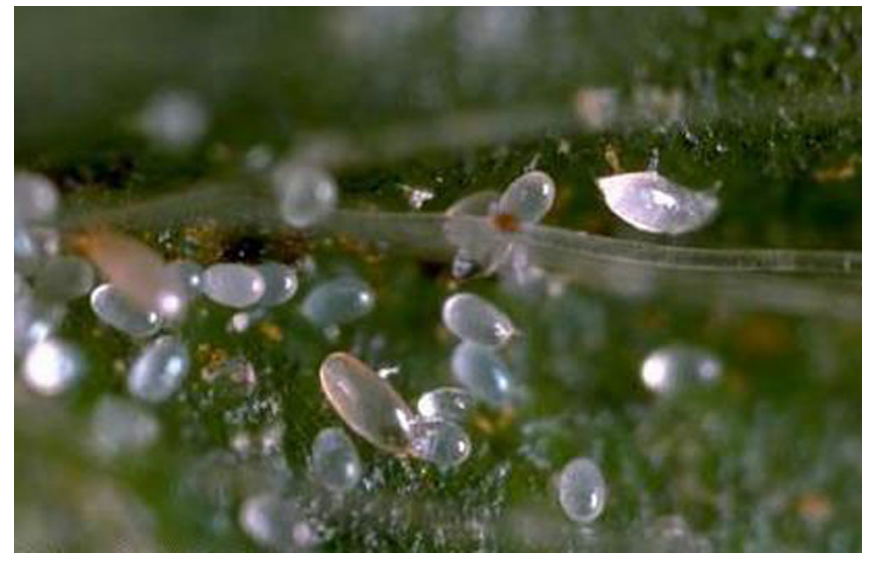

Figure 4. Cyclamen mite feeding on strawberry plants. Credits: J. Castellanos, UF/IFAS

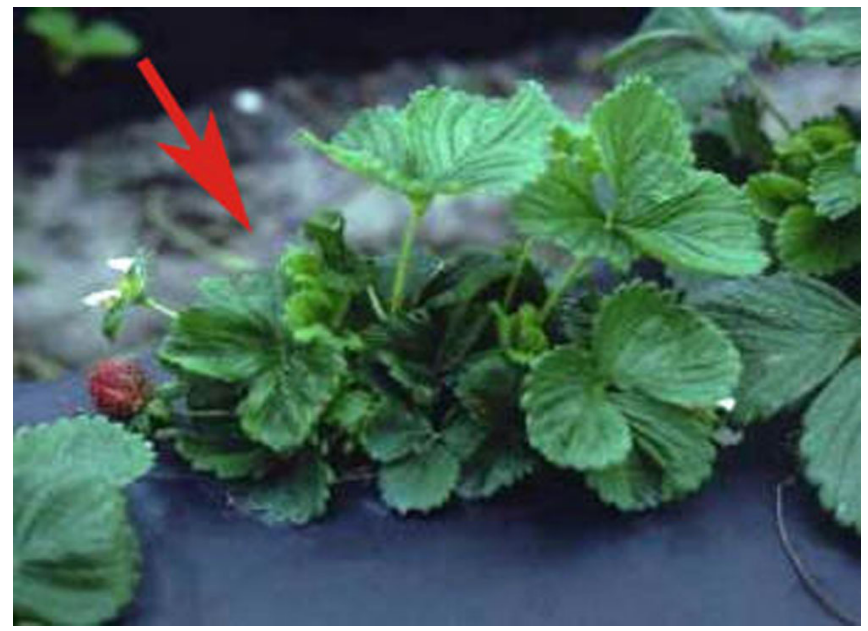

Figure 5. Cyclamen mite damage, petioles are short and leaves are thickened and wrinkled. Credits: J.F. Price, UF/IFAS

instars are the protonymph and the deuteronymph. Nymphs and adults are translucent. Nymphs have three pairs of legs while adults have four pairs. At $25-27^{\circ} \mathrm{C}\left(77-81^{\circ} \mathrm{F}\right)$, the life cycle can be completed in 10-12 days (Table 1). Females are slightly larger than males and lay approximately three eggs per day. The life-span of the adult is about 20 days (McMurtry and Croft, 1997; Krantz, 1978). The upper and lower temperature limits for $N$. californicus developmental range are $10-33^{\circ} \mathrm{C}\left(50-91^{\circ} \mathrm{F}\right)$ (Malais and Ravensberg, 2003). Neoseiulus californicus shows a feeding preference for the larval and nymphal stages of the twospotted spider mite when the pest is present at low densities (Malais and Ravenberg, 2003). However, N. californicus can survive for a few days without eating a prey by feeding solely on a diet of pollen (Malais and Ravensberg, 2003). 


\section{Neoseiulus californicus as a Biological Control Agent: Application of Predatory Mites}

Predatory mites have been used as an alternative to miticides on a variety of crops including strawberries (Rondon et al., 2004; Liburd et al., 2003, Giles et al., 1995, Van de Vrie and Price, 1994; Trumble and Morse, 1993), avocado (Hoddle et al., 1999), and other crops (Beard, 1999). Recommended release rates depend upon pest infestation level and crop, but one predatory mite per plant is the current recommendation suggested on strawberries for low infestations (1-5\% twospotted spider mite infestation) to moderate infestations (6-10\% twospotted spider mite infestation) (Fig.6). Releases in temperatures below $7.2^{\circ} \mathrm{C}\left(45^{\circ} \mathrm{F}\right)$ or above $29.5^{\circ} \mathrm{C}\left(85^{\circ} \mathrm{F}\right)$ should be avoided. Control of twospotted spider mite populations should start early because they reproduce quickly at high temperatures and low humidity. To scout a crop, one should select 100 leaflets per field (about 5-12 acres) randomly on a weekly basis. The undersides of leaves should be examined for the presence of twospotted spider mite with the aid of a $14 \mathrm{X}$ hand lenses. If populations of twospotted spider mites exceed $10 \%$ before predatory mites have been released, a compatible miticide, such as Acramite or Vendex, should be applied to reduce the pest density.

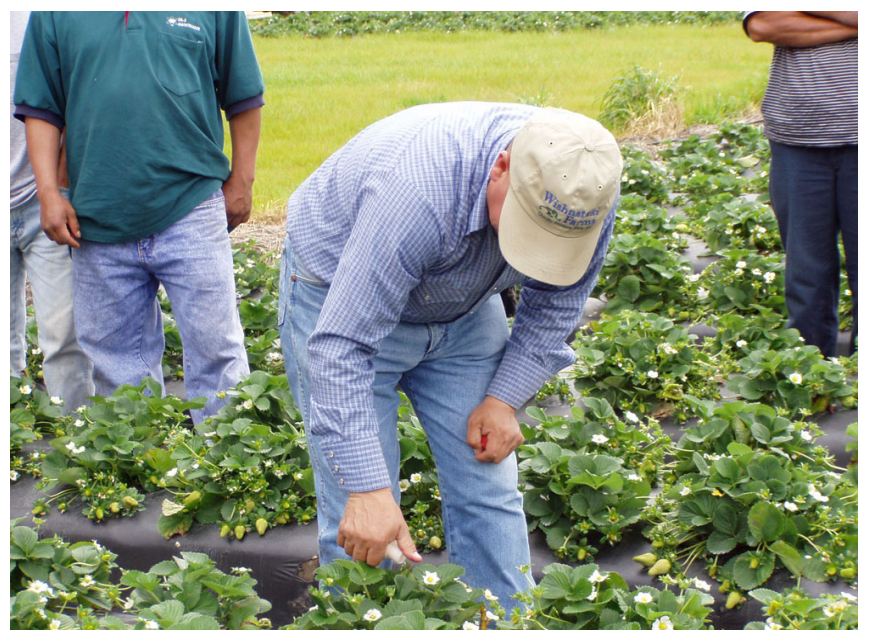

Figure 6. Demonstrating how to release predatory mites in the field. Credits: S.I. Rondon, UF/IFAS

\section{Literature Cited}

Beard, J.J. 1999. Taxonomy and Biological Control: Neoseiulus cucumeris (Acari: Phytoseiidae), a Case Study. Australian Journal of Entomology. 38:51-59.

Castagnoli, M. and S. Simoni. 1991. Influenza Della Temperature Sullincremento Delle Popolazioni di Amblyseius californicus (McGregor) (Acari: Phytoseiidae). Redia 74(2):621-640.

Giles, D.K., J. Gardner, and H.E. Studer. 1995. Mechanical Releases of Predacious Mites for Biological Pest Control in Strawberries. Trans. Amer. Soc. Agric. Engin. 38:1289-1296.

Hoddle, M.S. 2000. Using Neoseiulus californicus for Control of Persea Mite. California Avocado Research Symposium. Univ. Calif. Riverside. $\mathrm{N}^{\mathrm{O}} 787-4714$.

Hoddle, M.S., O. Aponte, V. Kerguelen, and J. Heraty. 1999. Biological Control of Oligonychus perseae (Acari: Tetranychidae) on Avocado: Evaluating Release Timing, Recovery, and Efficacy of Six Commercially Available Phytoseiids. Internat. J. Acarol. 25:211-219.

Johnson, W.T. and H.H. Lyon. 1991. Insects that Feed on Trees and Shrubs. $2^{\text {nd }}$ Edition. Comstock Publishing Associates. 560 p.

Krantz, G.W. 1978. A Manual of Acarology. Corvallis, Oregon State University, OR. 509 p.

Liburd, O.E, G.G. Seferina, and D.A. Dinkins. 2003. Suppression of Twospotted Spider Mites. In: UF/IFAS, Berry/Vegetable Times. November 2003.

Malais, M.H. and W.J. Ravensberg. 2003. Knowing and Recognizing: the Biology of Glasshouse Pests and Their Natural Enemies. Koppert B.V. and Reed Business Information. 288 pp.

McMurtry, J. and B. Croft. 1997. Life Styles of Phytoseiid Mites and Their Roles as Biological Control Agents. Ann. Rev. Entomol. 42:291-321. 
McMurtry, J.A. 1982. The Use of Phytoseiids for Biological Control: Progress and Future Prospects, pp. 23-48. In: Recent Advances in Knowledge of the Phytoseiidae. M. Hoy (Ed.). Univ. Calif. Press, Berkeley, Pub. 3284.

Rondon, S.I., D.J. Cantliffe, and J.F. Price. 2004. Best Management Practices Started the Strawberry Season. In: UF/IFAS, Berry/Vegetable Times. February 2004.

Trumble, J.T. and J.P. Morse. 1993. Economics of Integrating the Predaceous Mite Phytoseiulus persimilis (Acari: Phytoseiidae) with Pesticides in Strawberries. Hort. Entomol. 86(3):879-885.

Van de Vrie, M. and J.F. Price. 1994. Manual for Biological Control of Twospotted Spider Mites on Strawberry in Florida. UF/IFAS-GCREC.

DOV-1994-1. 
Neoseiulus californicus McGregor: A Predatory Mite Species for Controlling Twospotted....

Table 1. Developmental time of Neoseiulus californicus McGregor at 21,25 , and $33^{\circ} \mathrm{C}\left(70,77,91^{\circ} \mathrm{F}\right.$, respectively) with the twospotted spider mite, Tetranychus urticae Koch, as a food supply (modified from Castagnoli and Somini 1991).

\begin{tabular}{||l|c|c|c||}
\hline \multirow{2}{*}{ Developmental Stage (Days*) } & \multicolumn{2}{|c||}{ Temperature $\left.{ }^{*}{ }^{\circ} \mathbf{C}\right)$} & $\mathbf{3 3}$ \\
\cline { 2 - 4 } & $\mathbf{2 1}$ & $\mathbf{2 5}$ & 1.6 \\
\hline Egg & $3.1^{*}$ & 0.8 & 0.3 \\
\hline Larva & 1.0 & 1.7 & 1.0 \\
\hline Protonymph & 2.0 & 1.2 & 0.8 \\
\hline Deuteronymph & 1.4 & 5.9 & 3.7 \\
\hline Total egg-adult & 7.5 & 60 & 65 \\
\hline Total egg/female & 64 & 2.9 & 3.5 \\
\hline Eggs/female/day & 1.9 & & \\
\hline (Relative humidity of $75 \%)$ & & & \\
\hline \hline
\end{tabular}

